\title{
A TIME-VARYING ANALYSIS OF THE PUBLIC DEBT SUSTAINABILITY IN TURKEY WITH FLEXIBLE LEAST SQUARES TECHNIQUE
}

\author{
Cansın Kemal CAN ${ }^{1}$
}

\begin{abstract}
This paper gauges the sustainability of public debt in Turkey from a time-varying perspective. The time-varying estimation techniques exhibit the whole portrait of intertemporal variations in the sustainability of public debt. We estimated a fiscal reaction function using flexible least squares method to reap this benefit of timevarying models. This method is a practical alternative to the other approaches in the literature. The results suggest that public debt sustainability has been established in Turkey through a transformation in the early 2000s, but thereafter the fiscal performance has waned gradually. In recent years, the fiscal reaction parameter has hit negative levels after some 20 years of sturdiness. This finding indicates that the public debt is likely to become unsustainable should no necessary measures are promptly implemented. Nevertheless, the Covid - 19 pandemic appears to be an unexpected and important source of an impediment for the government to achieve short-run stabilisation goals by skyrocketing social expenditures and transfers.
\end{abstract}

Keywords: Flexible least squares, debt sustainability, fiscal reaction function

Jel Codes: H63, H61, H62

\section{ESNEK EN KÜÇÜK KARELER YÖNTEMI ILE TÜRKIYE'DEKI KAMU BORCU SÜRDÜRÜLEBILIRLIĞiNIN DINAMIK ANALIZi}

Öz

Bu makale, zamanla değişen (time-varying) bir perspektifte Türkiye'deki kamu borcunun sürdürülebilirliğini değerlendirmektedir. Zamanla değişen katsayılı tahminleme teknikleri, kamu borcunun sürdürülebilirliğindeki zamanlar arası değişimlerin bütün çerçevesini sergileme özelliğine sahiptir. Bu çalışma, zamanla değişen katsayılı modellerin avantajlarından yararlanmak için, esnek en küçük kareler yöntemini kullanarak bir mali tepki fonksiyonu tahminlemeyi amaçlamaktadır. Bu yöntem literatürdeki diğer modellere pratik bir alternatif olarak ön plana çıkmaktadır. Bulgular, kamu borçlarının sürdürülebilirliğinin 2000'li yılların başlarındaki bir dönüşümle sağlandığını, ancak daha sonra mali performansın kademeli olarak azaldığını göstermektedir. Son yıllarda, mali tepki parametresinin yaklaşık 20 yıllık güçlü bir seyrin ardından negatif seviyelere ulaştığı gözlemlenmektedir. Bu bulgu, gerekli tedbirlerin zamanında uygulanmaması durumunda kamu borcunun sürdürülemez hale gelebileceğini göstermektedir. Ancak, son dönemde ortaya çıkan Covid - 19 pandemisinin bu tür düzeltici politikaların kısa vadede uygulanmasını önleyen bir engel olarak ortaya çıktığı görülmektedir. Hızla artan sosyal harcamalar ve transferler kısa vadedeki toparlanmanın gerçekleşmesini önleyici rol oynayacaktır.

Anahtar Kelimeler: Esnek en küçük kareler, borç sürdürülebilirliği, mali tepki fonksiyonu Jel Kodları: H63, H61, H62

1 PhD, Istanbul Medeniyet University, Faculty of Political Sciences, Department of Public Finance, kemal.can@medeniyet.edu.tr, ORCID: 0000-0001-5365-0937 


\section{Introduction}

The last decades of Turkish public finances were shaped, to a large extent, by high indebtedness and malfunctioning fiscal policies that brought about substantial economic precariousness. As an outcome of these unfavourable conditions in the economy, public debt dynamics have largely been unstable, which constituted quite an impediment to the expansion of economic activities. Reducing fiscal manoeuvrability and restricting the social and economic policy tool traits of the budget, public debt spikes in Turkey generated a hindrance to the proper functioning of the economic system. In order to avoid such unpleasant scenarios, thorough scrutiny of the trajectory of the public debt and associated fiscal policies is crucial for the long-term performance of the fiscal balances. Also, investigating the existing disruptions in the fiscal posture is vital for elaborating on the potential imminent pathway of the public debt levels to avoid future challenges.

Given these arguments, it is the very purpose of this study to appraise the course of the public debt of Turkey during the last decades in an empirical manner. For this purpose, we estimate a fiscal reaction function in a time-varying context using the flexible least-squares technique. The methodological combination of this sort suits the requirements of our research question best since, for developing countries like Turkey, time-varying estimations reveal the best results due to the unsteady dynamics of the economy. Succinctly speaking, the fiscal reaction function gauges the existence and the extent of the retaliation by the government to the undesired upward movements in the public debt level. The positive reaction by the government to bring the public debt back to its stable trajectory is considered as evidence for the sustainability of the public debt in the fiscal reaction function literature. However, for precarious economies like Turkey, estimating this equation with time-invariant methods such as OLS leads to incomplete judgements about public debt sustainability since the dynamics of the fiscal balances varies swiftly across years. Hence, the nature of the economy entails an estimation technique that is time-varying to capture the proper dynamics of the fiscal posture.

The flexible least squares method is a straightforward and intuitive tool to capture the timevariance in the analysis. Therefore, it is preferred for the execution of the time-varying estimation. The primary contribution of our study to the academic literature is the dynamic analysis of public debt sustainability in Turkey within time-varying flexible least squares framework. To accomplish this objective, the study is developed under three sections. The first section discusses the theoretical issues regarding the fiscal reaction function and the flexible least-squares approach. The second section provides a brief review of the literature on the topic. The third section is devoted to empirics along with the analysis of the salient features of the data. The final section concludes and discusses the current and future posture of the fiscal balances based on the empirical findings in the third section.

\section{Theoretical Background}

\subsection{Basics of Fiscal Reaction Function}

Public debt sustainability is a vague concept, and the abundance of theoretical definitions of the public debt sustainability concept poses a challenge for the debt sustainability analyses to be carried out. Thus, transforming this concept into a clear-cut notion entails a concretising tool, and the fiscal reaction function serves exactly this purpose in the literature.

Borrowing is inevitable for any economy in the world since budgetary capacities are limited, but the public needs are not. From the public welfare perspective, borrowing has beneficial aspects, including fulfilling immediate needs or financing long-term, large-scale investments. Nevertheless, public debt accumulation might also have impairing effects, especially when the allocative decisions are not made wisely. Public financial mismanagement is the ultimate source of extreme public debt accumulation therefore, proper scrutiny of fiscal balances on a regular basis is crucial for managing the course of public debt in the country. Preserving the stable path of public debt level entails implementing proper financial management strategies that aim to prevent the 
public debt from hitting unrepayable levels. At this point, normative judgements regarding the quality of fiscal strategies are mostly misleading or inadequate. The consequences of inappropriate public debt policies include reduced fiscal space and fiscal manoeuvrability, continuously compounding interest payments on the existing debt, shrinking credibility, rising risk premium, declining public investments, increased likelihood of default, etc.

To shun these potential adverse consequences and to guard the economy against the sudden stops of foreign financial resources, the fiscal reactions of the government to mounting debt should be assessed thoroughly by means of an evaluation tool. This is when the fiscal reaction function comes into play. As the name suggests, this function gauges the degree of fiscal reactions performed by the government in an attempt to revert the severe upward movements in the public debt level. The fiscal reactions involve primary balance improvements to trim the unpleasant swings in public debt. A positive primary balance indicates that the interest payments are fully covered, and also a certain amount of existing public debt is reduced through excess balance. Thus, if the fiscal authorities' goal is to reduce existing public debt accumulation, then they need to run primary surpluses as a reciprocation.

The algebra behind this function is based on the debt dynamics, whose primary component is the intertemporal budget constraint. This constraint primarily suggests that the existing debt accumulation is an outcome of past budget deficits. The existing debt stock is the summation of previous debt, current budget deficit and interest payments along with other flows. Hence, in the existence of interest payments, financing the debt stock with new borrowing generates a vicious circle of debt spiral for the country which also defined as Ponzi financing (Domar, 1944, p.799).

Algebraically the intertemporal budget constraint can be described using the following notation:

$$
\begin{array}{lr}
D_{t}: \text { Debt Stock } & D_{t}=D_{t-1}+\Delta D_{t} \\
I_{t}: \text { Interest Expenditure } & I_{t}=i_{t} D_{t-1} \\
R_{t}: \text { Government Revenues } & \\
G_{t}: \text { Primary Spending } & \\
P B_{t}: \text { Primary Balance } & P B_{t}=R_{t}-G_{t} \\
i_{t}: \text { Nominal Interest Rate } & \\
r_{t}: \text { Real Interest Rate (Fisher Equation) } & r_{t}=\left(\frac{1+i_{t}}{1+\pi_{t}}\right)-1 \\
\pi_{t}: \text { Inflation } & \\
P_{t} Y_{t}: \text { Nominal GDP } & P_{t} Y_{t}=\left(1+\pi_{t}\right)\left(1+g_{t}\right) P_{t-1} Y_{t-1} \\
g_{t}: \text { Growth Rate } &
\end{array}
$$

The debt dynamics of the economy can be summarised with the following formula:

$$
G_{t}+i D_{t-1}-R_{t}+O T_{t}=\left(D_{t}-D_{t-1}\right)
$$

According to this formula, debt accumulation occurs as an outcome of government expenditures, interest payments on the previous public debt, government revenues and other flows of financial sources such as contingent liabilities. Solving for $D_{t}$ we get;

$$
D_{t}=\left(1+i_{t}\right) D_{t-1}-P B_{t}
$$

This formulation exhibits the nexus between current public debt, previous public debt and the primary balance. It can be observed that if the public debt level raises in the previous period ( $t-$ 1 ), then in the next period $(t)$ the government has to run a positive primary balance $\left(P B_{t}\right)$ to keep the total level of public debt unaffected by the surge in the previous period. 
In modern fiscal understanding, however, the level of public debt and/or primary balance is not as important as their position to the government's financial capacity. Thus, we scale the debt dynamics equation above with the GDP, a common indicator used for representing the capacity to pay (Jha, 2012, p. 22).

$\frac{D_{t}}{\underbrace{}_{d_{t} Y_{t}}}=\frac{\left(1+i_{t}\right)}{\left(1+\pi_{t}\right)\left(1+g_{t}\right)} \underbrace{\frac{D_{t-1}}{P_{t-1} Y_{t-1}}}_{d_{t-1}}-\frac{P B_{t}}{\underbrace{P_{t} Y_{t}}_{p b_{t}}}$

where $P_{t} Y_{t}=\left(1+\pi_{t}\right)\left(1+g_{t}\right) P_{t-1} Y_{t-1}$

Plugging the Fisher equation, we get,

$d_{t}=\frac{\left(1+r_{t}\right)}{\left(1+g_{t}\right)} d_{t-1}-p b_{t}$

Equation nine above represents the relationship between primary balance and the debt level in a clearer way by incorporating the real interest rate and growth rate as well. The lowercase letters indicate the ratio of the parameter to the capacity to pay. According to this equation, the debt level increases when the real interest rate rises. Also, the growth rate adversely affects the debt level, while a positive primary balance reduces the debt level. In this context, a positive primary balance is a fiscal reaction to the high level of public debt by the government. Even though there are other ways of reducing public debt, including inflation tax or new borrowing, primary balance generation is the proper way of debt reduction since the debt is reduced using the country's own resources. Thus, fiscal reaction function in a way tests the existence of the effort by the fiscal authorities to stabilise the public debt appropriately.

In its most general form, the fiscal reaction function is formalised as follows:

$$
p b_{t}=F\left(d_{t-1}, X_{t}\right)+\varepsilon_{t}
$$

The $X_{t}$ represents the other explanatory variables, including the output gap. According to Bohn (1995), to reap the full benefits of the fiscal reaction function, it is crucial to calibrate the explanatory variables. In the literature, the output gap is the most widely used parameter to be included in the model.

The dependent variable here is the primary balance since we are testing the fiscal reactions which are in the form of primary balance improvements to surging public debt. Also, the primary balance is not influenced by the interest payments since they are based on past debt, which is no longer controllable. Put differently, the primary balance excludes interest expenditures on the existing debt and thereby concentrates solely on the past debt itself. Hence, the expected sign for the coefficient of public debt explanatory variable is positive. In other words, the government should react by improving the primary balance when the public debt mounts.

However, expecting a positive sign for the entire sample is too restrictive a constraint and also seemingly unrealistic. In the real world, most countries are able to run a positive fiscal reaction only sporadically. Despite the fact that Bohn (1995) emphasises the importance of time-variance in the fiscal reaction parameter, he generally assumes an average fiscal reaction parameter for the entire sample, which is not approved by most academics. According to Canzoeri et al. (2001), for instance, the fiscal response parameter should be greater than zero for a larger portion of the sample in a time-varying setting. Operationally, this is still a stringent decision rule since it impels the government to run a positive fiscal reaction regardless of the economic conditions. There are more resilient arguments in the time-varying fiscal reaction function taxonomy in the literature, including Greiner and Fincke (2009) and its later version Greiner and Fincke (2015). According to their arguments, if the government is running a positive fiscal reaction in half of the sample, it is sufficient for public debt sustainability. Contrarily, if the response parameter is negative on average, then the public debt diverges from its stable path and becomes unsustainable in an explosive manner. The time-varying estimation techniques allow interpretations of the extent of 
the fiscal responses in sub-periods of the sample, making the analysis more realistic, unlike constant parameter models. There can be periods of positive and negative fiscal reactions, and thereby there can be periods of sustainable and unsustainable public debt throughout the years, but the idea is to keep positive fiscal reaction periods as long as possible.

In the empirical section, we adapt the fiscal reaction function used in Burger et al. (2012). The first reason for choosing this variant to assess Turkish public finances is that their reference country South Africa and Turkey are seemingly alike in many aspects. Being developing countries, their near economic histories are shaped by fluctuations and fiscal deficits are also common in the history of both countries. Besides, the Burger et al. (2012) approach to the fiscal reaction function is very convenient and practical for estimation thanks to its simplistic approach. Putting all these pieces together, we prefer the Burger et al. (2012) model, which can be summarised as follows in a nutshell.

Their version of the fiscal reaction function reads as follows:

$$
p b_{t}=\beta_{1}+\beta_{2} p b_{t-1}+\beta_{3} d_{t-1}+\beta_{4} \hat{y}_{t-1}+\varepsilon_{t}
$$

The first explanatory variable is the lagged values of the primary balance to test the inertia in fiscal policy. The governments are mostly reluctant to make swift changes in their fiscal policies, and the fiscal behaviour is generally carried over to the next period. Thus, $\beta_{2}$ coefficient measures the extent to which the fiscal policy changes over time.

The most important explanatory variable is obviously the lagged values of public debt since we are testing the primary balance reaction to this particular variable. The primary reason for using the lagged values of the variables in the model is that in many countries, the budget is prepared on an annual basis. Thus, if the fiscal authorities are to react to the debt spikes, they can only do so in the next budget year. This is the reason why they use lagged values on the explanatory side of the equation. Hence, the $\beta_{3}$ coefficient measures the magnitude of the fiscal reaction, and as we noted before, the expected sign for this parameter is positive for a sustainable fiscal posture. A negative value indicates an insufficient fiscal reaction or lack thereof. According to Bohn (1995), a positive coefficient is sufficient for sustainability and despite being a relatively resilient criterion, it is a practical rule of thumb for detecting sustainability in the fiscal balances. Hence, in our analysis, we will also seek a positive $\beta_{3}$ coefficient while estimating the fiscal reaction function.

Finally, the $\hat{y}_{t-1}$ is the output gap which tests the cyclical behaviour of the fiscal policies. A negative coefficient in front of this parameter indicates a procyclical fiscal behaviour which is very common in developing countries, according to Alesina et al. (2008). In developing countries, the people do not have full confidence in fiscal policies and therefore, when there is a boom in economic activities, they demand more public goods instead of preserving the excess funds for future dire periods. Hence, being a developing country, we can expect a negative sign for this parameter while empirically analysing Turkish public finances in section three.

\subsection{Basics of Flexible Least Squares Approach}

Conventional linear regression models assume constancy for the estimated parameters, but many developing countries, including Turkey have inherent structural instability, which is not captured by constant parameter models. In those countries, the dynamics of the economy exhibit time-varying properties and conditions change abruptly, which impedes the time-invariant models to portray the behaviour of the economic indicators properly. Those countries are mostly characterised by unexpected movements in the data, structural changes, and repeating transition periods, making the constant parameter models suffer from poor performance. This is when the time-varying estimation models come into play. In this type of estimation techniques, relaxing the constant parameter assumption facilitates the identification of the relationship between economic indicators. Time-varying estimation, as the name suggests, does not estimate a unique parameter for the entire sample but instead shows the evolution of the parameter over time. One of the 
contributions to the literature in time-varying estimation is Kabala and Tesfatsion (1989). Their approach is called "flexible least squares", and they aim to test the stability of the parameter by relaxing the constant parameter argument.

The standard OLS estimation involves the dependent variable $y_{t}$ explanatory variables $x_{1} \ldots . x_{p}$. According to the postulations of the model, $y_{t}$ can be approximated by $x_{t}^{\prime} \beta$ where $\beta$ is the vector of estimated parameters. In the regular OLS setting, the cost function to minimise is:

$$
C(\beta)=\sum_{t=1}^{T}\left(y_{t}-x_{t}^{\prime} \beta_{t}\right)^{2}
$$

In OLS taxonomy, the minimisation of the above summation is based on the assumption that there is no dynamically evolving linear dependence between $y_{t}$ and $x_{t}$ and that $y_{t}-x_{t}^{\prime} \beta \approx 0$. However, the FLS approach makes an additional assumption and states that $\beta_{t+1}-\beta_{t} \approx 0$ which formally allows the coefficients to vary over time. The practical aspect of the FLS approach is that it does not make any further assumptions about the residuals. The FLS approach estimates the coefficient for a particular period $t$ differently from the other periods. In this case, we don't have a unique $\beta$, but we have a parameter estimated for each period, namely, $\beta_{t}=\left(\beta_{1 t}^{\prime} \ldots \beta_{p t}^{\prime}\right)^{\prime}$.

To estimate these parameters, the FLS approach uses a different version of equation (12). In this case, the cost function to minimise becomes;

$$
C(\beta ; \mu)=\sum_{t=1}^{T}\left(y_{t}-x_{t}^{\prime} \beta_{t}\right)^{2}+\mu \sum_{t=1}^{T-1} \xi_{t}
$$

where;

$$
\xi_{t}=\left(\beta_{t+1}-\beta_{t}\right)^{\prime}\left(\beta_{t+1}-\beta_{t}\right) \text {. }
$$

Kalaba and Tesfatsion (1989) introduce an innovative algorithm for the minimisation procedure of equation (13). The detailed analysis of their estimation procedure is beyond the scope of this paper, but the curious reader might refer to Kalaba and Tesfatsion (1989) for the detailed explanation. However, it is possible to state the OLS estimation is a special case of the FLS method and FLS covers a larger set of possibilities, as evidenced by equation thirteen. In particular, the OLS can be thought of as a special method of aggregating the information stored in the FLS estimates. Hence, it can be concluded that FLS attempts to detect the coefficient vector appearing in each period $t$, whereas OLS aims at calculating the average coefficient vector over time.

\section{Literature Review}

Due to the reasons mentioned in the previous section, for a more profound analysis of fiscal stability, the fiscal reaction function needs to be estimated in a time-varying fashion. Bearing this idea in mind, in this study, we contribute to the academic literature on the fiscal reaction function by incorporating the flexible least squares methodology as an estimation technique. However, the literature on the time-varying estimation of the fiscal reaction function mostly involves state-space modelling, which is carried out by using Kalman filtering. Also, penalised spline estimation is another technique commonly used to obtain the time-varying parameters. In this section, we review some of the contributions to the time-varying estimation literature to reconcile our work with the existing literature. Nevertheless, in the empirical literature, the fiscal reaction function has been estimated using time-invariant settings as well. In this section, we include some examples of this type of analysis as well. Even though there is a plethora of academic works in the literature on fiscal sustainability, we only include selected contributions due to space scarcities.

The first attempt in the literature to estimate a fiscal reaction function empirically is Bohn (1995) and its later version Bohn (1998). Using the U.S. data, Bohn gauged the degree of fiscal sustainability and evaluated the fiscal responses by the U.S. government to stabilise public debt via the OLS method. His findings suggest that there is strong evidence for the existence of sufficient fiscal response exerted by the U.S. government. He recommends the use of control variables to 
avoid omitted variable bias and to reduce the deteriorating effect of poor performance by stationarity tests on the estimation quality.

Bohn (2007) augments the arguments in Bohn (1995) and Bohn (1998) using a longer data range. In this study, his findings once again indicate a positive response by the government to stabilise the public debt. The real importance of this study is the proposal by Bohn to use timevarying analysis to account for the dynamic evolution of the fiscal reaction parameter, which was one of the inspirations for our study.

Budina and Wijnberger (2007) is another seminal contribution to the empirical literature on the fiscal reaction function. In this study, they propose a combination of probabilistic simulations with steady-state analysis. To test the performance of their model, they use Turkish data even though their findings imply sustainability for Turkish public debt. According to them, the debt structure is precarious and thereby constitutes a source of uncertainty for the economy.

By using monthly data Mello (2008) empirically tests the existence of public debt sustainability in Brazil via a fiscal reaction function. His findings point out a positive reaction parameter for the country, which guarantees fiscal sustainability.

Afonso and Jalles (2011) estimate a panel version of the fiscal reaction function tailored for OECD countries. Their estimation results are suggestive that, overall, the OECD countries were able to run positive fiscal reaction to restore fiscal stability whenever needed.

Burger et al. (2012) appraise fiscal sustainability in Brazil by means of a fiscal reaction function. They estimate the function in different settings, including time-varying and time-invariant contexts. Their time-invariant estimations point to fiscal sustainability in the country, while timevarying setting results reveal that the sustainability did not exist for the entire sample and that it has been reached through a transformation in the fiscal policy of the country.

Another contribution in the panel data form is Mauro et al. (2015). They use the rolling coefficients method for the estimation. The empirical findings show that whenever the debt level exceeds a certain threshold, the fiscal reaction parameter weakens, reducing the likelihood of public debt sustainability.

Mutuku (2015) analyses the fiscal sustainability in Kenya. For this purpose, he estimates a fiscal reaction function using a data set covering 1970 - 2013. His findings evidence no systematic fiscal reaction therefore, he concludes that the fiscal posture in Kenya is not sustainable. As a policy recommendation, he proposes the implementation of long-run fiscal adjustments.

Fincke and Greiner (2011) estimate a time-varying fiscal reaction function by implementing the penalised spline technique on the data for selected Eurozone countries. Their results are indicative of sustainability for all countries except Greece and Italy. They transform the OLS form of the fiscal reaction function into time-varying setting since they believe that the data generating process is not linear and time-varying setting brings the model closer to the real process.

Burger and Marinkov (2012) use the time-varying fiscal reaction function to elaborate the fiscal sustainability in South Africa. They calculate the differential between the fiscal reaction parameter and the real interest rate and growth differential. According to their findings, the South African government has established fiscal sustainability through transformations in the near history. Also, Burger et al. (2012) estimate a state-space version of the time-varying fiscal reaction function, and similar results also appear in this study, indicating a transformation in fiscal policies to stabilise debt employing corrective fiscal reactions in the 90s. Their findings are also suggestive that, since 1946, the government has performed well in fiscal reaction generation to trim the unpleasant movements in public debt whenever needed.

Nguyen et al. (2016) estimated a time-varying fiscal reaction function in a state-space format using U.S. data. They test the sustainability of public debt in the U.S in an intertemporal setting by 
using the fiscal reaction function as a tool. According to the results, the fiscal reaction parameter was positive until 2005, indicating a sustainable public debt position, but thereafter the parameter hit the negative zone, which means that the government has gradually lost its reactive power in fiscal management. The authors also state that fiscal stability has become even more exacerbated by the global financial crisis due to mounting public debt and falling primary balances.

Belguith and Gapsi (2016) test the existence of fiscal stability in Tunisia by means of a timevarying fiscal reaction function using a smoothing spline technique. They found out that the fiscal reaction parameters are mostly positive, indicating a sustainable debt position for Tunisian public finances.

Campos and Cysne (2019) apply the time-varying methodology to monthly data to evaluate the fiscal stability in Brazil. For this purpose, they use three techniques together: State-space, penalised spline smoothing and time-varying cointegration. Their findings are suggestive that the positive fiscal response of the Brazilian government shrinks over time which indicates the government can respond to mounting debt with falling degrees of intensities. The falling trend in the fiscal strength brings the country into an unsustainable position.

\section{Empirics}

In this section, based on the theoretical framework of the previous sections, we empirically analyse the public debt sustainability in Turkey using fiscal reaction function as a tool. We estimate this function by flexible least squares methodology which was described in the first section, which allows for time-varying estimation of parameters.

To carry out the task of empirical analysis of public debt sustainability in Turkey, this section is developed under three sections. In the next subsection, we provide an overview of the data by highlighting its distinctive properties, and in the second subsection, we evaluate the estimation results obtained from the time-varying estimation of the fiscal reaction function and interpret the course of public debt sustainability in Turkey.

\subsection{Salient Features of the Data}

As we looked into in the first section, the fiscal reaction function is based on two main indicators: the public debt to GDP ratio and the primary balance to GDP ratio. However, in the literature, some other auxiliary variables are added to the equation in the form of control variables to avoid omitted variable bias such as output gap, government revenue or expenditure gap etc. In this study, we use output gap as a control variable calculated using H.P. filter by setting lambda value equal to 6.2 which is recommended by Ravn and Uhlig (2002) as the optimal level for annual data. Returning to the main indicators, the dependent variable is, without doubt, is primary balance since we measure the fiscal reaction of the government, which are in the form of primary balance improvements. Graph one below plots the primary balance realisations in Turkey in the near history.

The first point to note on the graph is that negative primary balances fully characterise the portion of the graph which represents the pre-90s section. Numerous factors contributed to this outcome, including closed economic structure, military coups, currency restrictions, global petroleum crises, etc. The negative trend in the primary balance prevails until the mid-90s, when it also hits record low levels. Following the IMF programme in the second half of the 90s, the primary balance reaches the positive territory, but this transition was not long-lasting, and at the end of the decade, the primary balance returns to negative levels as an outcome of the economic crisis at the beginning of the new decade. Strong commitment to the renewed IMF programme by the government resulted in a remarkable improvement in the primary balance, which is crucial for establishing sustainability in public debt. 
Figure 1: Primary Balance (Scaled by GDP)

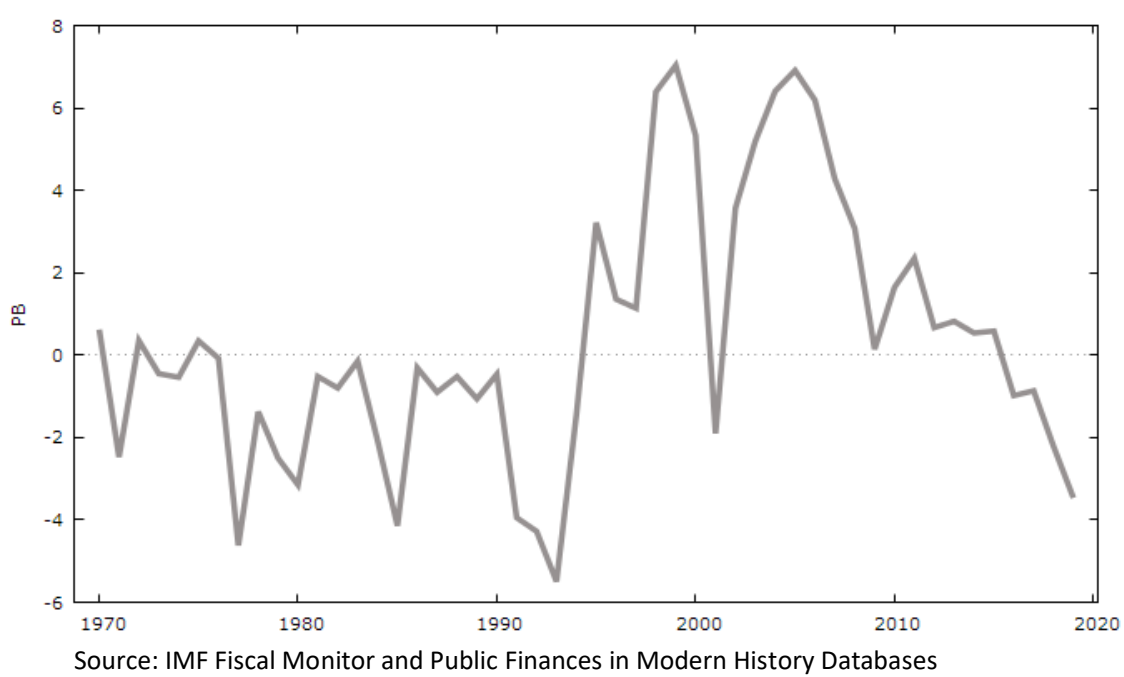

Nevertheless, this positive trend in the public finances did not happen to be long-lasting, and through the end of the 2000s, the primary balance started deteriorating once again. During the global crisis, it plunged instantly and recorded near-zero levels after years of public financial triumph. During the years following the global crisis, the primary balance exhibited some recovery, but this trend has also been short-lived, and in recent years, the primary balance is in the negative zone emitting signals for upcoming unsustainability in the public debt.

Figure 2: Public Debt to GDP (Scaled by GDP)

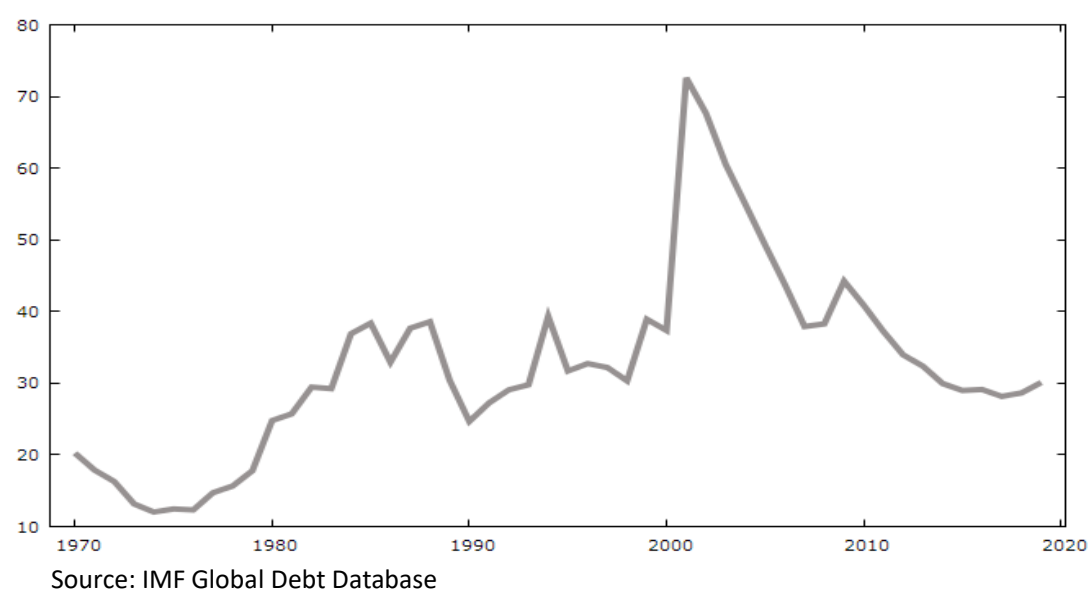

The main explanatory variable in the model, on the other hand, is the public debt which is also scaled by GDP since we are testing the magnitude of the fiscal reciprocation to assess the public debt sustainability in Turkey. The graph above illustrates the debt to GDP ratio for the estimation period. At first glance, it is visible on the graph that the public debt oscillates within the $20-40 \%$ band with the exception of 2001 when it topped out. In 2001, the country experienced its most severe economic crisis, which caused primary balances and GDP to shrink abruptly and also resulted in a skyrocketing public debt. During the early 2000s, the persistent primary balance generation which can be seen in Figure 1 above, brought about a remarkable decline in the public debt. Recently, the public debt pattern is seemingly stable, but an unexpected rise in the last couple of years is worth noticing since they can pose a serious threat to public finance stability in the near future. 


\subsection{Empirical Analysis}

\subsubsection{Stationarity of the Series}

We start this section with the stationarity analysis of the data set since it is one of the assumptions of the OLS on which the flexible least squares approach is based. According to Bohn (1995), however, formal stationarity tests perform weakly in detecting the stationarity in near-unit root cases, especially in annual data with small samples. Since our data set is rather small with fifty observations in annual frequency, we start stationarity analysis by the visual inspection of the data and correlograms.

Figure 3: ACF and PACF for Primary Balance

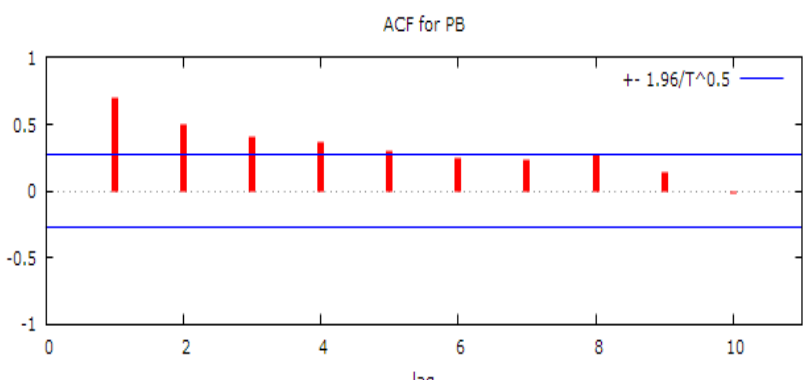

lag

PACF for PB

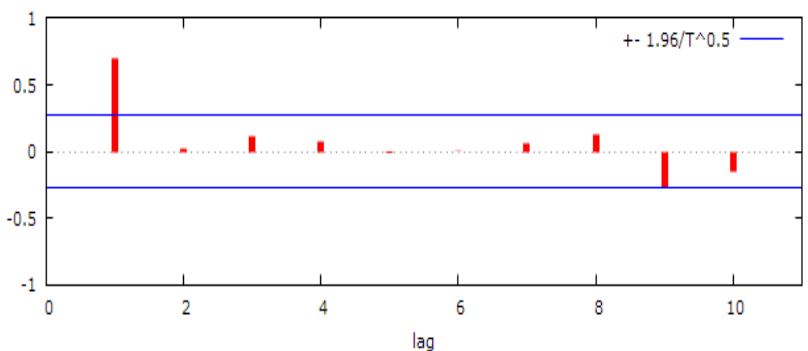

$\operatorname{lag}$

Figure 4: ACF and PACF for Public Debt

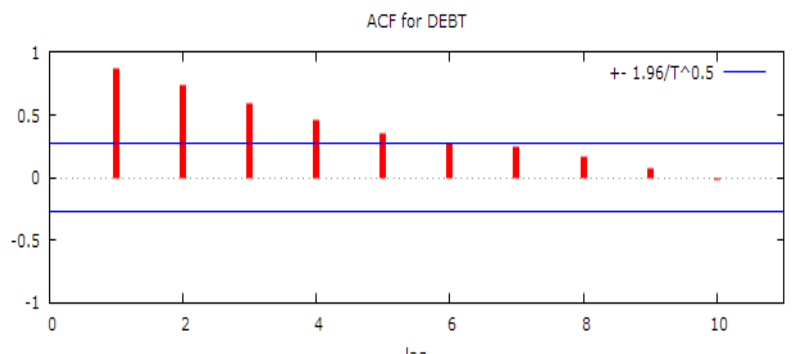

lag

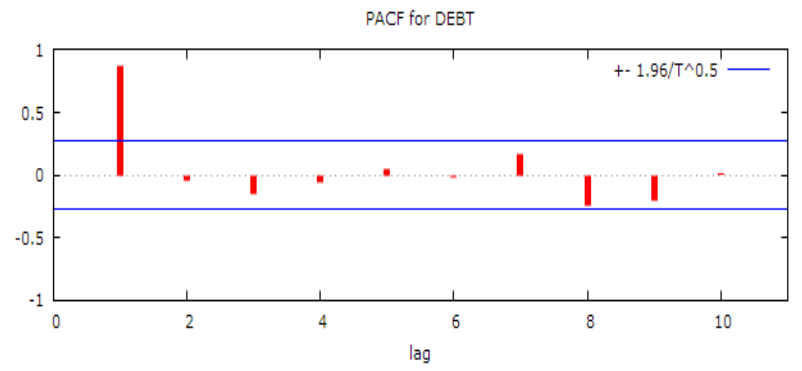


By observing the two data graphs above (figures 1 and 2), as a preliminary sign of stationarity, it is visible that both series oscillate within certain intervals outside some exceptional years. In other words, no stable trend is visible on both graphs, which is indicative of stationarity. The correlograms allow additional visual inspections regarding the stationarity of the series. An abrupt fall in partial PACF and/or gradual decay in ACF are suggestive that the data series is stationary. The figures above plot the correlograms of the public debt and primary balance indicators in the model. In Figures 3 and 4, the abrupt fall in PACF and the gradual decay in ACF are clearly visible, which provide quite a hint about the stationarity of those series. Hence, it is possible to conclude that the visual inspection of the data and the findings are supporting the stationarity of the series in the model.

Now that we have an overall idea derived from the visual inspection, we can enhance the stationarity argument with formal tests. Even though the formal tests exhibit poor performance in distinguishing stationary series from nonstationary ones when applied to annual data with short samples, their results for the model are provided in the table below to detect the stationarity of the data. According to table one, the primary balance is stationary for all five tests at different levels of significance, whereas the public debt is stationary for four tests since the ADF test cannot reject the null hypothesis of a unit root at any level. However, the inadequacy of the ADF test in detecting stationarity in public debt series was mentioned in Bohn (1995) and therefore, this result was in a way expected. Since the other four tests indicate stationarity for the public debt at different levels of significance, along with the visual inspection carried out above, it is safe to conclude that the public debt series is also stationary as well. Finally, the output gap is also stationary according to the results of the four tests above and therefore, and this series can also be deemed stationary.

Table 1: Formal Stationarity Test Results (Level)

\begin{tabular}{|c|c|c|c|c|c|}
\hline & ADF & DF-GLS & PP & KPSS & ERSP \\
\hline Primary Balance & $-2,68$ & $-2,72$ & $-2,68$ & 0,23 & 2,28 \\
\hline $1 \%$ & $-3,57$ & $-2,61$ & $-3,57$ & 0,73 & 1,87 \\
\hline $5 \%$ & $-2,92$ & $-1,94$ & $-2,92$ & 0,46 & 2,97 \\
\hline $10 \%$ & $-2,59$ & $-1,61$ & $-2,59$ & 0,34 & 3,91 \\
\hline Required Primary Balance & $-2,59$ & $-1,83$ & $-4,59$ & 0,57 & 6,89 \\
\hline $1 \%$ & $-3,60$ & $-2,62$ & $-3,60$ & 0,73 & 1,87 \\
\hline $5 \%$ & $-2,93$ & $-1,94$ & $-2,93$ & 0,46 & 2,97 \\
\hline $10 \%$ & $-2,60$ & $-1,61$ & $-2,60$ & 0,34 & 3,91 \\
\hline Output Gap & 7,33 & $-0,66$ & $-7,3$ & 0,02 & 2,14 \\
\hline $1 \%$ & $-3,57$ & $-2,62$ & $-3,57$ & 0,73 & 1,87 \\
\hline $5 \%$ & $-2,92$ & $-1,94$ & $-2,92$ & 0,46 & 2,97 \\
\hline $10 \%$ & $-2,59$ & $-1,61$ & $-2,59$ & 0,34 & 3,91 \\
\hline
\end{tabular}




\subsubsection{Estimation Results}

In this section, we interpret the estimation results obtained from flexible least squares estimation. Nevertheless, to fully grasp the intuition behind these results, it is essential to first look into the OLS outcomes on which the FLS method is based.

The OLS estimation results of the fiscal reaction function described in the first section are summarised below:

The estimated equation was;

$p b_{t}=\beta_{1}+\beta_{2} p b_{t-1}+\beta_{3} d_{t-1}+\beta_{4} \hat{y}_{t-1}+\varepsilon_{t}$

The OLS results are ( $t$ values in parenthesis) :

$p b_{t}=-2.082+0.631 p b_{t-1}+0.066 d_{t-1}-0.061 \hat{y}_{t-1}+\varepsilon_{t}$
$(-2.36) \quad(5.88)$
(2.50)
$(-2.01)$

Adjusted $\mathrm{R}^{2}=0.64$

$$
\begin{array}{r}
\text { Autocorrelation: } \quad F=0.486 \quad \text { Prob }=0.618 \\
\text { Obs } * R^{2}=1.08 \quad \text { Prob }=0.581 \\
\text { Heteroskedasticity (White): } F=1.11 \quad \text { Prob }=0.37 \\
\text { Obs } * R^{2}=10.001 \text { Prob }=0.35
\end{array}
$$

According to those results, the government's fiscal behaviour is pretty much carried over to the next period, which is evidenced by the 0.631 value of the parameter of the autoregressive term. In other words, it is evident that the government is rather conservative in making amendments in the fiscal policy design. The output gap parameter appears to be negative, which indicates that the fiscal policy in Turkey is mostly procyclical, which means that when there is a boom in the economy, the government increases expenditures and transfer payments instead of raising financial accumulation for the future. As we noted earlier, according to Alesina et al. (2008) this type of procyclical fiscal behaviour is common in developing countries due to politico-economic preferences.

Finally, the most important parameter in the model is obviously the fiscal reaction parameter, $\beta_{3}$, and it is positive on the articulation above, which suggests that the public debt is sustainable in the long run. A positive fiscal reaction parameter, 0.066 in the above equation, means that the government is positively responding to upward movements in the public debt, which, according to Bohn (1995), guarantees public debt sustainability.

Nevertheless, this argument is valid only from a narrow perspective. The constant parameter setting does not allow for the interpretation of the short-run movements in the fiscal reaction parameter. In practice, exerting the same amount of fiscal reaction is not viable for every year. The capacity of the fiscal authority to generate fiscal reaction varies from year to year, and for this reason, the fiscal reaction function needs to be estimated in a time-varying fashion. In the first section, we introduced the flexible least squares technique which can be used as a method for this purpose. Figure 5 below illustrates the time-varying fiscal reaction parameter estimated by the flexible least squares method.

The graph below clearly illustrates that the evolution of the fiscal reaction parameter can be partitioned into two subsections. The first subsection is from $1970-1994$, and the second one is from 1995 - 2019. It is visible on the graph that the first part is dominated by negative values of the fiscal reaction parameter, whereas positive values of the parameter generally shape the second one. This shift from negativity to positivity in the fiscal reaction parameter is an outcome of the recovery programs supervised by the IMF. Before the 90 s, there were also occasional attempts to 
control the public debt dynamics, but they failed for several reasons, including the closed structure of the economy, currency and trade restrictions, oil crises, military coups etc. The liberalisation of the country and fully open financial market structure facilitated the occurrence of positive fiscal reaction parameters in the country. However, even the positive fiscal reaction values in the late 90 s were insufficient to avoid the fiscal crises at the end of the decade and previously in 2001 . The lack of sufficient structural reforms was the primary reason for this unfavourable outcome. The required profound policy alterations were carried out during the first years of the single-party government in the early 2000s. Hence, it is no surprise that the fiscal reaction parameter tops out in this period. Returning to Figure 2, it can be observed that the most prominent decline in the public debt to GDP ratio, not surprisingly, corresponds to the section where the fiscal reaction parameter is also the highest in Figure 5.

Figure 5: Time-Varying Fiscal Reaction Parameter (FLS Estimation)

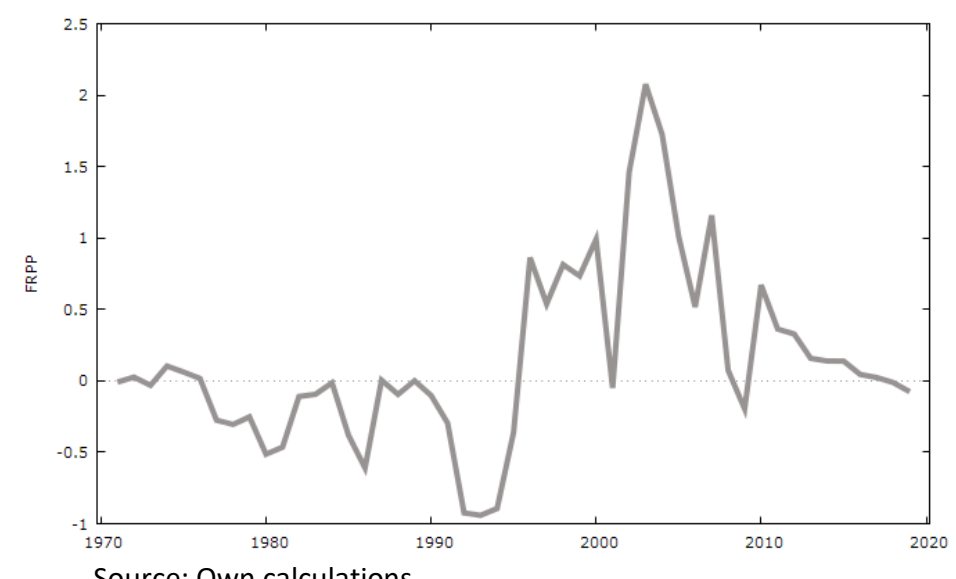

Nevertheless, the strong pathway of the reaction parameter has been put on pause by the global crisis at the end of the decade, and thereafter, it has not been able to reach its previous levels of success. Recently, it has hit negative levels once again after some twenty years of positivity. This trend raises concerns about the future course of public debt sustainability since negative fiscal reaction parameters might bring about unsustainable debt positions very swiftly. Hence, the required policy alterations should be implemented promptly to avoid a potential debt crisis in the near future. Quitting the use of procyclical fiscal policies, building up public confidence by primary balance generation, implementing full-fledged tax reform, restructuring contingent liabilities, proper scrutiny of expenditures, reducing profligacy are among the policy options available for the government. However, despite the existence of numerous policy alternatives, the current Covid-19 pandemic appears to be quite an impediment for fiscal recovery in the short-run (Can and Canoz, 2020).

\section{Conclusion}

Public debt sustainability is a dynamic concept and is inherently time-varying. In the modern economic world, the economic conditions change very swiftly therefore appraising the debt sustainability with a constant parameter model exerts a poor performance in capturing the whole framework. The constant parameter models have the ability to give an idea about the long-run average conditions about the sustainability of public debt, whereas time-varying models are able to portray the evolution of the debt sustainability over time which provides hints about the future course of the pathway of public finances. Bearing these arguments in mind, in this study, we evaluated the sustainability of public finances in a time-varying manner by estimating the fiscal reaction function in a flexible least squares format. The findings are indicative that the long-run parameter values are in favour of sustainability, while the time-varying parameters suggest that the sustainability of public debt in Turkey is not stagnant and persistent but is contingent and 
changes over time. In other words, the point which OLS estimation fails to make is that the public debt in Turkey is not always sustainable, and there are periods of unsustainable public debt in recent history. However, the time-varying findings suggest that recently Turkey is about to find itself in another episode of unsustainable public debt, which is evidenced by negative values of fiscal reaction parameters. Plummeting the fiscal reaction parameter values is a clear sign of unsustainable public debt in the near future.

Reversing this trend is an onerous task and entails numerous fiscal policy alterations. Turkey has managed to divert the downward trend in the fiscal reaction parameter in the early 2000s but, by the time the government had declared that the primary balance generation was a priority for fiscal policy design, unlike the current position. At the moment, it is hard to see such a commitment by the government regarding primary balance generation, which makes the fiscal portrait even more gloomy for the future. Postponing the execution of fiscal policies to secure primary balance is likely to compel the government to pursue front-loading adjustments in the future, which are more painful for society. In other words, hitherto neglected policy implementations might bring about more serious fiscal problems in the future. Hence, the government should promptly apply policy alterations to change the current course of fiscal reaction parameter otherwise, the public debt sustainability will become a major concern for the economic policy in the short-run.

The policy alterations available to the government include reducing extravagance and profligacy through proper scrutiny of expenditures, restructuring contingent liability schemes, fullfledged tax reform etc. However, despite the fact that there is an abundance of alternative fiscal policies available to the government, apparently, the Covid-19 pandemic is likely to make the whole procedure of fiscal policy design even more arduous for the government since the mounting health expenditures and transfer payments constitute a great deal of additional burden on the budget which is unlikely to expire in the near future.

\section{References}

Afonso, A., \& Jalles, J. (2011). Appraising Fiscal Reaction Functions. Economics Bulletin, 31(4), 33203330.

Alesina, A., Campante, F. R. and Tabellini, G. (2008). Why is Fiscal Policy Often Procyclical? Journal of the European Economic Association, 6(5), 1006-1036.

Argitis, G., \& Nikolaidi, M. (2014). The financial fragility and the crisis of the Greek government sector. International Review of Applied Economics, 28(3), 274-292. DOI: 10.1080/02692171.2013.858667

Baldacci, E., McHugh, J., \& Petrova, I. K. (2011B). Measuring Fiscal Vulnerability and Fiscal Stress: A Proposed Set of Indicators. IMF Working Papers, 1-20.

Baldacci, E., Petrova, I. K., Belhocine, N., Dobrescu, G., \& Mazraani, S. (2011A). Assessing fiscal stress. IMF Working Papers, 1-41.

Belguith, S. and Gabsi, F. (2017). Public Debt Sustainability in Tunisia: Empirical Evidence Estimating Time-Varying Parameters. Journal of the Knowledge Economy, 10, 550-560.

Bohn, H. (1995). The Sustainability of Budget Deficits in a Stochastic Economy. Journal of Money, Credit and Banking, 27(1), 257-71.

Bohn, H. (1998). The Behavior of U. S. Public Debt and Deficits. The Quarterly Journal of Economics, 113(3), 949-963.

Bohn, H. (2007). Are Stationarity and Cointegration Restrictions Really Necessary for the Intertemporal Budget Constraint? Journal of Monetary Economics, 54(7), 1837-1847.

Budina, N., \& Wijnbergen, S. (2007). Quantitative Approaches to Fiscal Sustainability Analysis: A New World Bank Tool Applied to Turkey. Washington: World Bank Policy Research. 
Burger, P. and Marinkov, M. (2012). Fiscal Rules and Regime-Dependent Fiscal Reaction Functions: The South African Case. OECD Journal on Budgeting, 12(1), 1-29.

Burger, P., Stuart, I., Jooste, C. and Cuevas, A. (2012). Fiscal Sustainability and The Fiscal Reaction Function for South Africa: Assessment of the Past and Future Policy. South African Journal of Economics, 80, 1-19.

Campos, E. L. and Cysne, R. P. (2019). A Time-Varying Fiscal Reaction Function for Brazil. Estudos Econômicos, 49(1), 5-38.

Canzoneri, M., R.E, C. and Diba, B. (2001). Is the Price Level Determined by the Needs of Fiscal Solvency? American Economic Review, 91(5), 1221-1238.

Can, C.K., Canoz i. (2020) Testing Minsky's Financial Fragility Hypothesis for Turkey's Public Finances Public Finance Quarterly, 2020/4 497- 514.

Domar, E. (1944). The "Burden of the Debt" and the National Income. The American Economic Review, 34(4), 798-827.

Fincke, B. and Greiner, A. (2011). How to assess debt sustainability? Some theory and empirical evidence for selected euro area countries. Applied Economics, 44(28), 3717-3724.

Greiner, A. and Fincke, B. (2009). Public Debt and Economic Growth. Berlin: Springer.

Greiner, A. and Fincke, B. (2015). Public Debt, Sustainability and Economic Growth: Theory and Empirics. London: Springer International Publishing.

IMF Global Debt Database. https://www.imf.org/external/datamapper/CG_DEBT_GDP@DD/TUR

IMF Public Finances in Modern History Database. https://www.imf.org/external/datamapper/pb @PP/TUR

IMF Fiscal Monitor Database. https://www.imf.org/external/datamapper/dataset/FM

Jha, R. (2012). Analytical Approaches to Assessing Public Debt Sustainability. In B. Ferrarini, J. R., and A. Ramayandi, Public Debt Sustainability in Developing Asia (pp. 14-43). Oxfordshire: Routledge.

Kalaba, Robert, E and Tesfatsion, L. (1989), Time-Varying Linear Regression Via Flexible Least Squares, Computers and Mathematics with Applications vol. 17 no. 08/09/09, pp. 12151245.

Mauro, P., Romeu, R., Biinder, A., \& Zaman, A. (2015). A Modern History of Fiscal Prudence and Profligacy. 76, 55-70.

Mello, L. (2008). Estimating a Fiscal Reaction Function: the Case of Debt Sustainability in Brazil. Applied Economics, 40(3), 271-84.

Mutuku, C. (2015). Assessing Fiscal Policy Cyclicality and Sustainability: A Fiscal Reaction Function for Kenya. Journal of Economics Library, 2(3), 173-191.

Nguyen, T., Suardi, S. and Chua, C. (2016). The Behaviour of U.S Public Debt and Deficits During The Global Financial Crisis. Contemporary Economic Policy, 35(1), 201-215.

Ravn, M. O. and Uhlig, H. (2002). On Adjusting The Hodrick-Prescott Filter for the Frequency of Observations. The Review of Economics and Statistics, 84(2), 371-380. 
